\title{
Nutrients release and phosphorus distribution during oligochaetes predation on activated sludge
}

\author{
Yuansong Wei ${ }^{\mathrm{a}, *}$, Hui Zhu ${ }^{\mathrm{a}}$, Yawei Wang ${ }^{\mathrm{a}}$, Jinfu $\mathrm{Li}^{\mathrm{b}}$, Peixin Zhang ${ }^{\mathrm{b}}$, Ji Hu${ }^{\mathrm{b}}$, Junxin Liu ${ }^{\mathrm{a}}$ \\ a Research Center for Eco-Environmental Sciences, Chinese Academy of Sciences, P.O. Box 2871, Beijing 100085, PR China \\ ${ }^{\mathrm{b}}$ Research Centre for National Isotope Engineering Technology, China Institute of Atomic Energy, P.O. Box 275, Beijing 102413, PR China
}

\section{A R T I C L E I N F O}

\section{Article history:}

Received 19 May 2008

Received in revised form 1 October 2008

Accepted 6 October 2008

\section{Keywords:}

Activated sludge

Nutrients release

Oligochaetes

Radioisotope ${ }^{32} \mathrm{P}$ tracer

Sludge reduction

Wastewater treatment

\begin{abstract}
A B S T R A C T
Release of nitrogen and phosphorus into effluent of activated sludge process was reported in the recent researches of sludge reduction induced by oligochaetes. In this study, batch test and radioisotope ${ }^{32} \mathrm{P}$ tracer test were therefore carried out to further investigate nutrients release and phosphorus distribution among supernatant, sludge and worm during predation of oligochaetes on sludge. Results showed that more nutrients release into supernatant occurred in the tests of worms with sterilized sludge than that of worms with activated sludge, and release of nitrogen and phosphorus was few in the tests of worms with activated sludge. Statistical analysis showed that no factor was significantly correlated with phosphorus concentration in the supernatant, but time and worm were only two factors significantly affecting total nitrogen (TN) concentration in the supernatant in the test of worms with activated sludge. Through test of radioisotope ${ }^{32} \mathrm{P}$ tracer, ${ }^{32} \mathrm{P}$ mainly distributed in activated sludge and supernatant, and more release of ${ }^{32} \mathrm{P}$ into the supernatant occurred in the test of sludge with worms. After $24 \mathrm{~h},{ }^{32} \mathrm{P}$ concentration of supernatant in the test of sludge with worms was $9 \%$ higher than that in the test of sludge without worms, and ${ }^{32} \mathrm{P}$ concentration of worm increased by $2.7 \%$. Additionally, the release rate of phosphorus into supernatant caused by worm's predation on activated sludge was $0.1211 \mathrm{mgTP} / \mathrm{gWorm}$ (wet weight) h.
\end{abstract}

(C) 2008 Elsevier B.V. All rights reserved.

\section{Introduction}

One of the most widely used methods for biological wastewater treatment was the conventional activated sludge (CAS) process, which produces large amount of excess activated sludge. If not properly disposed, the excess activated sludge may pose a potential threat to both the environment and the human health because of heavy metals, organic pollutants and pathogen. Sewage sludge treatment and disposal is, therefore, becoming one of the most serious challenges in wastewater treatment plants (WWTPs) as a result of legal constraints, rising costs and public sensitivity. For example, the cost of excess sludge treatment and disposal can account for up to 60\% of the total operating cost of WWTPs [1]. As a result, new methods of reducing sludge production are therefore urgently required. Current strategies for reducing sludge production are based on these mechanisms: lysis-cryptic growth, uncoupling metabolism, maintenance metabolism and predation on bacteria [1]. The strategies for sludge reduction should be evaluated and chosen for practical application using costs analysis and assessment of environmental impact. High costs still limit the wide

\footnotetext{
* Corresponding author. Tel.: +8610 62923543; fax: +86 1062849108 .

E-mail address: yswei@rcees.ac.cn (Y.Wei).
}

use of technologies such as sludge ozonation-cryptic growth and membrane bioreactor (MBR). Bioacclimation and harmness to environment are major bottlenecks for chemical uncoupler in practical application. In contrast, sludge reduction induced by oligochaete may present a cost-efficient way for WWTP if unstable worm growth was solved. Recently, many studies have focused on sludge reduction induced by protozoa and metazoa grazing on bacteria, and the performance of oligochaetes on sludge reduction in biological wastewater treatment has been paid more attention than that of protozoa [2-20]. Principal taxa of worms present in activated sludge systems and trickling filters are Naididae, Aeolosomatidae and Tubificidae.

In general, nutrients such as nitrogen and phosphorus are required to treat organic substances in biological wastewater treatment processes. Parts of nutrients are incorporated into the biomass, and then withdrawn with excess sludge. During sludge mineralization an increase of phosphorus, nitrogen, $\mathrm{CO}_{2}$ and even dissolved chemical oxygen demand (COD) in effluent does not seem avoidable [1]. Hence, it should be paid more attention to such strategies as lysis-cryptic growth and predation on bacteria, because nutrients release into effluent increases downstream nutrient removal requirements and results in eutrophication and deoxygenation in the receiving waters. Release of nitrogen and phosphorus into effluent of activated sludge process was 
reported in the recent researches of sludge reduction induced by oligochaetes $[3-7,9-12,16,19]$. The average $\mathrm{PO}_{4}{ }^{3-}-\mathrm{P}$ concentration in the effluent was higher about $14-20 \%$ than that in the influent in the CAS process at the range of $50-150$ total worms/mgVSS (volatile suspended solids) of worm density. It was interestingly found in both MBR and CAS reactors that worm growth did not cause $\mathrm{PO}_{4}{ }^{3-}-\mathrm{P}$ increase in the effluent during Aeolosoma dominance, but $\mathrm{PO}_{4}{ }^{3-}-\mathrm{P}$ increase in the effluent occurred as Nais was dominant. Statistics analysis also showed that Nais growth had an impact on the $\mathrm{PO}_{4}{ }^{3-}-\mathrm{P}$ concentration in the effluent [10]. Liang et al. [16] reported that total phosphorus (TP) removal's fluctuation in a bench scale of activated sludge process was weakened as the density of Aeolosoma hemprichi increasing. A statistical analysis showed that the removals of $\mathrm{NH}_{4}{ }^{+}-\mathrm{N}$ and TP were not significantly correlated with the density of $A$. hemprichi. In Huang's study [19], phosphorus was released, which led to TP concentration increase in the effluent and hence a slight decrease in TP removal in a recycled sludge reduction reactor at Tubifex tubifex density of $2500 \mathrm{mg} \mathrm{L}^{-1}$, compared with the control reactor. Results of batch tests clearly showed that the increasing rates of dissolved COD, ammonia and phosphorus produced in the predation of $T$. tubifex increased in correspondence with dry weights of $T$. tubifex organisms, and their increasing rates were $0.09 \mathrm{mgCOD} / \mathrm{mgTubifexd}, 0.03 \mathrm{mgNH}_{4}{ }^{+}-\mathrm{N} / \mathrm{mgTubifex} \mathrm{d}$ and $0.0006 \mathrm{mgTP} / \mathrm{mgTu}$ ifex $\mathrm{d}$, respectively.

It is no doubt that worm bloom can cause the release of nitrogen and phosphorus into effluent. However the nutrients release and its distribution among supernatant, sludge and worms are not clear in sludge reduction induced by oligochaetes. Considering microbes in activated sludge are active and may re-utilize nutrients released from worm's predation on sludge, therefore the purpose of this study was to compare the nutrients release when activated sludge and sterilized sludge were used as substrates for oligochaetes in batch tests in order to further understand nutrients release by worm's predation on activated sludge. In addition, to our knowledge, the distribution of phosphorus in sludge reduction induced by oligochaetes has not yet been undertaken although it is necessary for a more accurate understanding of nutrients release. In this study, the radioisotope ${ }^{32} \mathrm{P}$ tracer test was used to quantify the distribution of phosphorus and phosphorus release rate in sludge reduction induced by oligochaetes.

\section{Materials and methods}

\subsection{Batch tests}

Samples of activated sludge were taken from the wastewater treatment station of Research Center for Eco-Environmental Sciences (RCEES), Chinese Academy of Science (CAS). The activated sludge was firstly filtered by a 40 mesh $(0.42 \mathrm{~mm}$ of pore size) screen for removing inorganic particles before batch tests [21]. The initial sludge concentration in batch tests was adjusted at about $2 \mathrm{~g} / \mathrm{L}$ with the supernatant of activated sludge. Oligochaetes used in this study were bought from a local fish market, in which Lumbriculida hoffmeisteri was dominant. Before batch test, no additional substrate or nutrient but only the filtered sludge was used to feed oligochaetes for about 2 weeks in order to adapt worms to the activated sludge as substrate.

For comparing nutrients release of sludge reduction induced by oligochaetes, batch tests were designed for two groups as shown in Table 1, including Group 1 (sterilized sludge as substrate for worms) and Group 2 (activated sludge as substrate for worms). The sterilized sludge was prepared from the activated sludge by an autoclave at $121^{\circ} \mathrm{C}$ for $30 \mathrm{~min}$. The control tests were set as sludge without worms for both Group 1 and Group 2. Flasks of $50 \mathrm{~mL}$ contained $200 \mathrm{mg}$ of worms (wet weight), $10 \mathrm{~mL}$ of sludge at about $2 \mathrm{~g} / \mathrm{L}$ and $20 \mathrm{~mL}$ of deionized water. Additionally, tests of worms without any sludge were carried out to investigate nutrients release during worm growth without any substrate, in which flasks of $50 \mathrm{~mL}$ contained $200 \mathrm{mg}$ of worms (wet weight) and $30 \mathrm{~mL}$ of deionized water. All batch tests were carried out in flasks set in a shaker controlled at $20^{\circ} \mathrm{C}$ and $50 \mathrm{rpm}$ for 20 days.

\subsection{Sampling and analytic methods}

Samples of batch tests were randomly taken on Days $0,3,6$, 10,15 , and 20, respectively. Flasks were taken out from the shaker and then settled for $30 \mathrm{~min}$, and $5-10 \mathrm{~mL}$ of supernatant was sampled from flasks and treated with $0.45 \mu \mathrm{m}$ of filter for determining $\mathrm{PO}_{4}{ }^{3-}-\mathrm{P}$, TP and TN concentrations.

All oligochaetes in sampled flasks were firstly separated from the mixed liquor with a pipette of $5 \mathrm{~mL}$, and then washed using deionized water for cleaning solids attached on worm's surfaces. The wet weight of all these worms was determined by an electronic scale after drying worm's surface water with filter paper. The washing water containing solids was collected together with the mixed liquor for determining concentration of total suspended solids (TSS).

Concentrations of $\mathrm{PO}_{4}{ }^{3-}-\mathrm{P}, \mathrm{TP}, \mathrm{TN}$ and TSS were determined according to standard method [21]. All the values of $\mathrm{PO}_{4}{ }^{3-}-\mathrm{P}, \mathrm{TP}, \mathrm{TN}$ and TSS were the average of triplicate samples. Statistical analysis, including Pearson correlations and Spearman's rank correlations, was carried out with a software of SPSS 11.0 produced by SPSS Inc. (Chicago, IL).

\subsection{Test of radioisotope ${ }^{32} \mathrm{P}$ tracer}

Different from emission of carbon and nitrogen as gaseous form, it is easier to monitor the changes of phosphorus using radioisotope ${ }^{32} \mathrm{P}$ during sludge reduction induced by oligochaetes. In order to clearly investigate the fate of phosphorus during worm's predation on activated sludge, the radioisotope ${ }^{32} \mathrm{P}$ was selected as the tracer in the test, and changes of its radioactivity were therefore monitored among supernatant, activated sludge and worm body in the test of radioisotope ${ }^{32} \mathrm{P}$ tracer for $24 \mathrm{~h}$. The test of radioisotope ${ }^{32} \mathrm{P}$ tracer $\left(T_{1 / 2}=14.3 \mathrm{~d}\right)$ was carried out in Research Centre for National Isotope Engineering Technology, China Institute of Atomic Energy (CIAE). In this test, the radioisotope ${ }^{32} \mathrm{P}$ tracer would be step by step transferred from artificial wastewater to worms through a food-chain (activated sludge cultivated by artificial wastewater

Table 1

The operational conditions of batch tests.

\begin{tabular}{|c|c|c|c|c|}
\hline \multirow[t]{2}{*}{ Item } & \multicolumn{2}{|l|}{ Group 1} & \multicolumn{2}{|l|}{ Group 2} \\
\hline & \multicolumn{2}{|c|}{ Sterilized sludge } & \multicolumn{2}{|c|}{ Activated sludge } \\
\hline Sludge concentration $(\mathrm{g} / \mathrm{L})$ & $1.69 \pm 0.11$ & $1.69 \pm 0.11$ & $2.15 \pm 0.20$ & $2.15 \pm 0.20$ \\
\hline Oligochaetes (mg) (wet weight) & No worm & 200 & No worm & 200 \\
\hline Sampling time & \multicolumn{2}{|c|}{ Days $0,3,6,10,15$, and 20} & \multicolumn{2}{|c|}{ Days $0,3,6,10,15$, and 20} \\
\hline Temperature $\left({ }^{\circ} \mathrm{C}\right)$ & \multicolumn{2}{|c|}{20} & \multicolumn{2}{|c|}{20} \\
\hline
\end{tabular}


with exogenous $\mathrm{Na}_{2} \mathrm{H}^{32} \mathrm{PO}_{4}$, and predation of worms on activated sludge).

In this test, the radioisotope ${ }^{32} \mathrm{P}$ tracer of $\mathrm{Na}_{2} \mathrm{H}^{32} \mathrm{PO}_{4}$ provided by CIAE, $0.774 \mathrm{mCi}$ of radioisotope activity, was used as the exogenous phosphorus and added in the artificial wastewater. The composition of $400 \mathrm{~mL}$ artificial wastewater was as follows: $\mathrm{C}_{6} \mathrm{H}_{12} \mathrm{O}_{6}$ (glucose), $0.4 \mathrm{~g}$; $\left(\mathrm{NH}_{4}\right)_{2} \mathrm{SO}_{4}, 0.1 \mathrm{~g} ; \mathrm{Na}_{2} \mathrm{H}^{32} \mathrm{PO}_{4} \cdot 12 \mathrm{H}_{2} \mathrm{O}$, $0.1 \mathrm{~g} ; \mathrm{NaHCO}_{3}, 0.07 \mathrm{~g} ; \mathrm{KI}, 0.07 \mathrm{~g} ; \mathrm{MgSO}_{4}, 0.05 \mathrm{~g} ; \mathrm{CaCl}_{2}, 0.03 \mathrm{~g}$; Peptone, $0.01 \mathrm{~g}$; micronutrients solution (including $\mathrm{FeCl}_{3}, \mathrm{H}_{3} \mathrm{BO}_{3}$, $\mathrm{CoCl}_{2}, \mathrm{MnCl}_{2}, \mathrm{ZnSO}{ }_{4}, \mathrm{Na}_{2} \mathrm{MoO}_{4}$, and $\left.\mathrm{CuSO}_{4}\right), 1 \mathrm{~mL}$.

After filtered by a 40 mesh screen, the activated sludge from the wastewater treatment station of RCEES, CAS was adjusted at $2-2.5 \mathrm{~g} / \mathrm{L}$ of TSS concentration. For eliminating the effect of phosphorus in wastewater on radioisotope ${ }^{32} \mathrm{P}$ tracer test, the activated sludge after filtration needs washing by deionized water. And the activated sludge after washing was then centrifuged at $4000 \mathrm{rpm}$ for $10 \mathrm{~min}$, and the supernatant of activated sludge was discarded. Such washing activated sludge by deionized water was carried out three times. After washing, the activated sludge was aerobically cultivated at $25^{\circ} \mathrm{C}$ by the artificial wastewater with the radioisotope ${ }^{32} \mathrm{P}$ tracer in a beaker of $500 \mathrm{~mL}$ for $10 \mathrm{~h}$.

The activated sludge marked by the radioisotope ${ }^{32} \mathrm{P}$ tracer was then washed three times with deionized water after aerobic cultivation to eliminate effect of the radioisotope ${ }^{32} \mathrm{P}$ tracer in artificial wastewater on the following tests. After washing, the activated sludge was re-suspended in a pre-aerated deionized water of $500 \mathrm{~mL}$, and its concentration was adjusted at the range of $1.0-2.0 \mathrm{~g} / \mathrm{L}$ for worm's predation. In the following tests, the mixed liquor at $1.45 \pm 0.06 \mathrm{~g} / \mathrm{L}$ of TSS was filled in flasks of $25 \mathrm{~mL}$, each of which contained $5 \mathrm{~mL}$ of mixed liquor and $10 \mathrm{~mL}$ of deionized water. Among these flasks, one group of flasks was put with 10 mature worms, and another group of flasks without worms was set as the control. Sampling for both groups was carried out at Hours $0,2,4,8,12$, and 24, respectively. Radioisotope activities for the radioisotope ${ }^{32} \mathrm{P}$ tracer in supernatant, activated sludge and worms were determined by a Packard Tri-Carb 1050 TR/LL liquid scintillation counter. The values of ${ }^{32} \mathrm{P}$ activities were the average of triplicate samples. For calculating the real phosphorus amount in the radioisotope ${ }^{32} \mathrm{P}$ tracer test, the TP concentration in the initial activated sludge marked by radioisotope ${ }^{32} \mathrm{P}$ tracer was measured by the standard method [22] to determine the coefficient between the radioactivity of ${ }^{32} \mathrm{P}$ and phosphorus amount in activated sludge.

\subsection{Calculation}

The amounts of nutrients release and nutrients release rate were calculated as follows:

- For batch tests of worm's predation on sludge, including sterilized sludge and activated sludge

$$
\begin{aligned}
\Delta M_{t} & =M_{\text {test }}-M_{\text {control }} \\
& =\left[\left(C_{\mathrm{i}}-C_{0}\right)_{\text {test }} V_{\text {test }}\right]-\left[\left(C_{\mathrm{i}}-C_{0}\right)_{\text {control }} V_{\text {control }}\right]
\end{aligned}
$$

where $\Delta M_{t}$ is the mass difference of nutrients release into the supernatant, including $\mathrm{PO}_{4}{ }^{3-}-\mathrm{P}, \mathrm{TP}$ and TN, between the test and the control at the time of $t, \mathrm{mg} ; M_{\text {test }}$ and $M_{\text {control }}$ are the mass of nutrients release into the supernatant, including $\mathrm{PO}_{4}{ }^{3-}-\mathrm{P}, \mathrm{TP}$ and $\mathrm{TN}$, in the test group and the control group at the time of $t$, respectively, mg; $C_{\mathrm{i}}$ and $C_{0}$ are the nutrient's concentrations of the supernatant at the time of $t$ and the initial time of tests, respectively, $\mathrm{mg} / \mathrm{L} ; V_{\text {test }}$ and $V_{\text {control }}$ are the volume of the mixed liquor in the test group and the control group, respectively, L.
- For batch tests of worms without any sludge

$\Delta M_{t}=M_{t}-M_{0}=\left(C_{\mathrm{i}}-C_{0}\right) V$

where $\Delta M_{t}$ is the mass difference of nutrients release, including $\mathrm{PO}_{4}{ }^{3-}-\mathrm{P}, \mathrm{TP}$ and TN, at the time of $t, \mathrm{mg} ; M_{t}$ and $M_{0}$ are the nutrients mass of the supernatant, including $\mathrm{PO}_{4}{ }^{3-}-\mathrm{P}, \mathrm{TP}$ and $\mathrm{TN}$, at the time of $t$ and the initial time of tests, respectively, mg; $C_{\mathrm{i}}$ and $C_{0}$ are the nutrient's concentrations of the supernatant at the time of $t$ and the initial time of tests, respectively, $\mathrm{mg} / \mathrm{L}$; $V$ is the volume of the mixed liquor, $\mathrm{L}$.

\section{Results and discussion}

\subsection{Nutrients release in batch tests}

\subsubsection{Nutrients release}

Changes of $\mathrm{PO}_{4}{ }^{3-}-\mathrm{P}, \mathrm{TP}$ and TN concentrations and their releases into the supernatant of batch tests during 20 days are shown in Figs. 1 and 2, respectively. As clearly shown in Fig. 1, nutrients release occurred in all these three tests including Group 1, Group 2 and worm without sludge, and nutrients concentrations in the supernatant in the tests of worm with sludge including sterilized sludge and activated sludge were much higher than those in the tests of worm without sludge. In addition, phosphorus released in these tests mainly consists of ortho-phosphate.

It was obvious in Fig. 2 that the behavior of phosphorus release was totally different in both groups, which showed much more release of $\mathrm{PO}_{4}{ }^{3-}-\mathrm{P}$ and TP into supernatant in Group 1 of sterilized sludge with worms than in Group 2 of activated sludge with worms, though concentrations of $\mathrm{PO}_{4}{ }^{3-}-\mathrm{P}$ and TP in supernatant of Group 1 were lower than those of Group 2 (Fig. 1). In tests of Group 1 with sterilized sludge, concentrations of $\mathrm{PO}_{4}{ }^{3-}-\mathrm{P}$ and $\mathrm{TP}$ in supernatant of sludge without worms were stable at about $4 \mathrm{mg} / \mathrm{L}$, but those of sludge with worms increased very much, e.g. from $3.52 \mathrm{mg} / \mathrm{L}$ of TP on Day 0 to $13.09 \mathrm{mg} / \mathrm{L}$ of TP on Day 20. In tests of Group 2 with activated sludge, changes of $\mathrm{PO}_{4}{ }^{3-}-\mathrm{P}$ and $\mathrm{TP}$ concentrations in supernatant showed the same increasing trend in the tests of both sludge without worms and sludge with worms, e.g. from $3.10 \mathrm{mg} / \mathrm{L}$ of TP on Day 0 to $27.69 \mathrm{mg} / \mathrm{L}$ of TP on Day 20. However, it is noted that $\mathrm{PO}_{4}{ }^{3-}-\mathrm{P}$ and TP concentrations in the supernatant of sludge without worms were nearly the same as those of sludge with worms. The possible explanation is that part of activated sludge in the tests of sludge without worms were disintegrated due to no substrate (only deionized water) and then resulted in phosphorus release. Additionally, it was interestingly found that all the releases of $\mathrm{PO}_{4}{ }^{3-}-\mathrm{P}, \mathrm{TP}$ and $\mathrm{TN}$ in the tests of sterilized sludge without worms were nearly the same as those in the tests of worm without any sludge (Fig. 1).

Different from releases of $\mathrm{PO}_{4}{ }^{3-}-\mathrm{P}$ and TP in these batch tests, the behavior of TN release was the same in the tests of both groups, i.e., higher $\mathrm{TN}$ concentrations of the supernatant in the tests of sludge with worms than that in the tests of both sludge without worm and worm without sludge, and nearly the same TN concentrations in the tests of sludge without worm and worm without sludge (Fig. 1). It is interestingly found in the tests of both groups (sterilized sludge and activated sludge) that the TN concentration in the supernatant released from the sludge with worms was higher than that from sludge without worms. As the main composition of the released phosphorus, ortho-phosphate is easily utilized by bacteria in activated sludge and then resulted in the above-mentioned behavior of $\mathrm{PO}_{4}{ }^{3-}-\mathrm{P}$ and TP. And this different behavior of TN release may be explained as following: the released TN caused by worm's predation on sludge may have different compositions, i.e., more organic nitrogen than ammonia, and thus led to difficult utilization of nitrogen by living bacteria in activated sludge. However, 

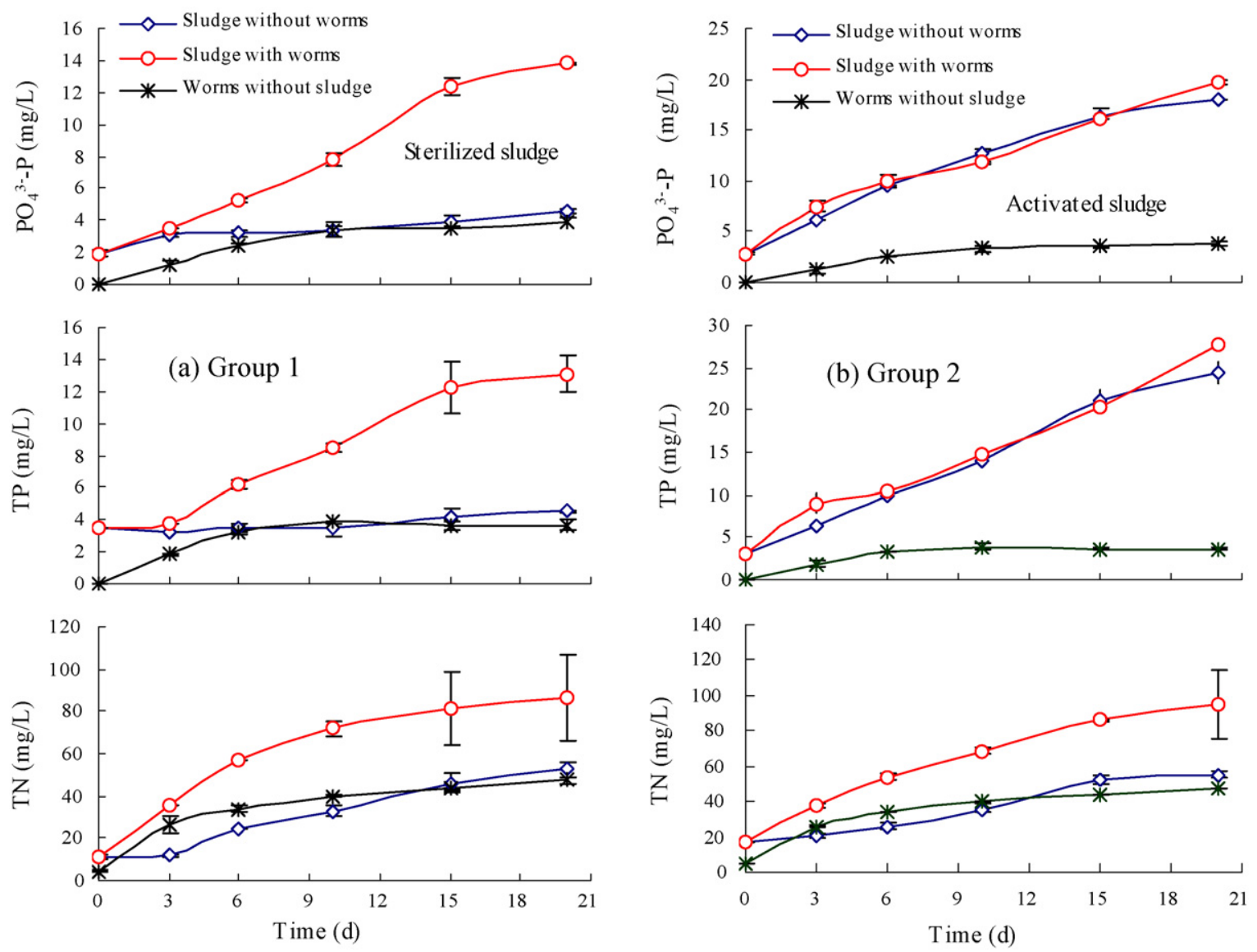

Fig. 1. Changes of $\mathrm{PO}_{4}{ }^{3-}-\mathrm{P}, \mathrm{TP}$ and TN concentrations in the supernatant during batch tests: (a) Group 1 of sterilized sludge and (b) Group 2 of activated sludge.

such behavior of TN release in the tests of sludge with worms needs further investigation.

As shown in Fig. 2, both nitrogen and phosphorus release occurred in all these three batch tests after 20 days, and the amounts of TN released into the supernatant were much more than those of $\mathrm{PO}_{4}{ }^{3-}-\mathrm{P}$ and TP in all these three tests. In addition, the amounts of $\mathrm{TN}, \mathrm{PO}_{4}{ }^{3-}-\mathrm{P}$ and $\mathrm{TP}$ released into the supernatant in the tests of sludge with worms were more than those in the
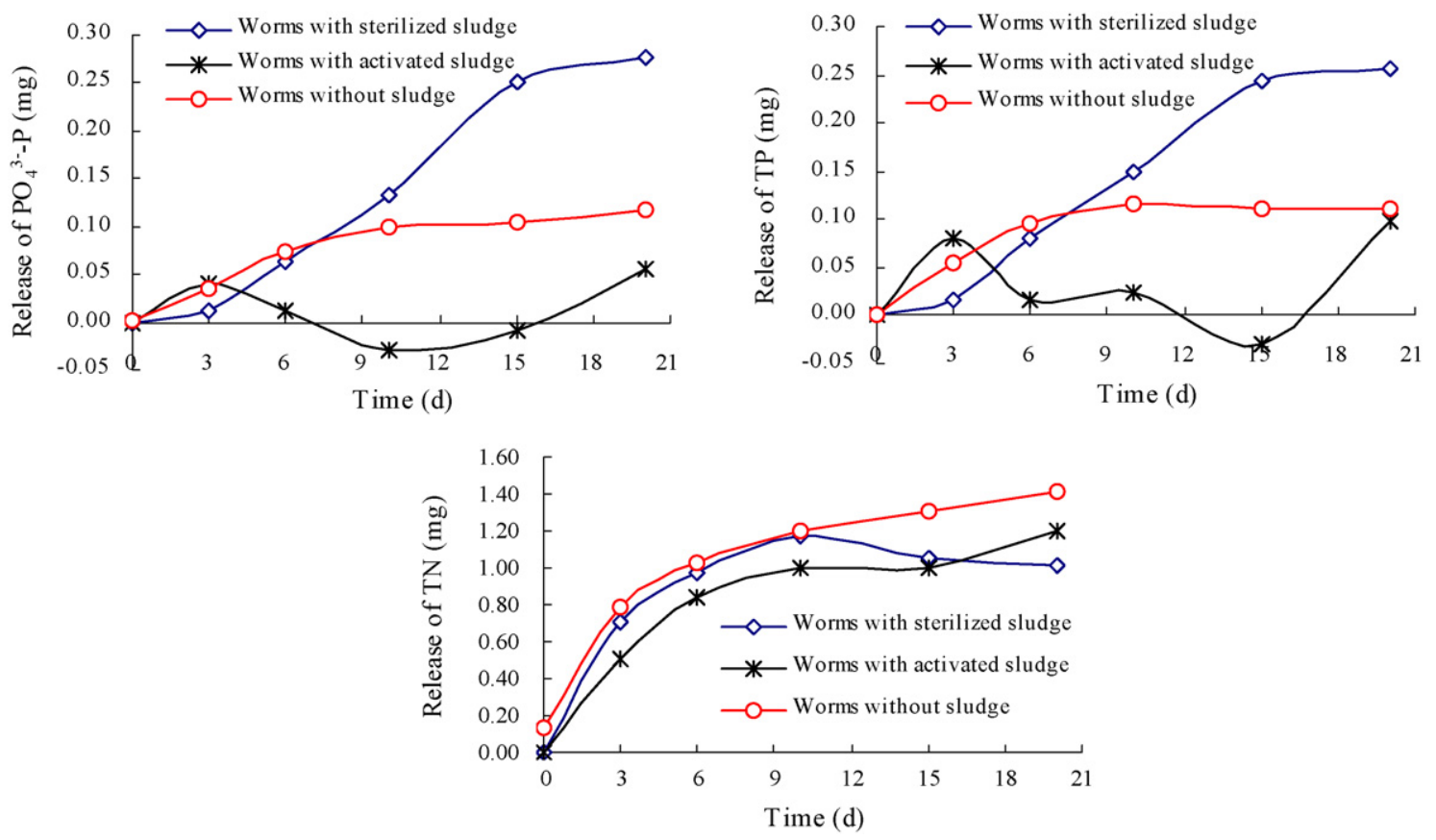

Fig. 2. Comparison of $\mathrm{PO}_{4}{ }^{3-}-\mathrm{P}, \mathrm{TP}$ and $\mathrm{TN}$ releases into the supernatant of tests of worms with sterilized sludge, worms with activated sludge and worms without sludge. 
Table 2

Pearson correlations among sludge reduction, worm wet weight and nutrients release in the batch tests.

\begin{tabular}{|c|c|c|c|c|c|}
\hline & Worms (wet weight) & Sludge reduction (SR) & $\mathrm{PO}_{4}{ }^{3-}-\mathrm{P}$ & TP & TN \\
\hline \multicolumn{6}{|c|}{ Batch tests of sterilized sludge with worms } \\
\hline Time $(t)$ & $-0.942^{* *}$ & $-0.910^{*}$ & $0.983^{* *}$ & $0.981^{* *}$ & 0.708 \\
\hline Worms (wet weight) & & 0.786 & $-0.922^{* *}$ & $-0.951^{* *}$ & -0.878 \\
\hline Sludge reduction (SR) & & & $-0.960^{* *}$ & $-0.939^{* *}$ & -0.446 \\
\hline $\mathrm{PO}_{4}^{3-}-\mathrm{P}$ & & & & $0.995^{* *}$ & 0.652 \\
\hline TP & & & & & 0.713 \\
\hline \multicolumn{6}{|c|}{ Batch tests of activated sludge with worms } \\
\hline Time $(t)$ & $-0.997^{* *}$ & $-0.875^{*}$ & 0.197 & 0.224 & 0.887 \\
\hline Worms (wet weight) & & $0.858^{*}$ & -0.199 & -0.213 & -0.906 \\
\hline Sludge reduction (SR) & & & -0.320 & -0.129 & -0.583 \\
\hline $\mathrm{PO}_{4}^{3-}-\mathrm{P}$ & & & & $0.814^{*}$ & 0.082 \\
\hline $\mathrm{TP}$ & & & & & 0.224 \\
\hline
\end{tabular}

${ }^{*}$ Correlation is significant at the 0.05 level (2-tailed).

** Correlation is significant at the 0.01 level (2-tailed).

tests of sludge without worms, no matter how sterilized sludge or activated sludge was. Obviously, the addition of worms in the sterilized sludge resulted in more phosphorus release than that in the activated sludge, i.e., $0.27 \mathrm{mg} \mathrm{PO}_{4}{ }^{3-}-\mathrm{P}$ and $0.26 \mathrm{mg} \mathrm{TP}$ in the tests of worms with the sterilized sludge, and only $0.06 \mathrm{mg}$ $\mathrm{PO}_{4}{ }^{3-}-\mathrm{P} 0.10 \mathrm{mg}$ TP in the tests of worms with the activated sludge. The amounts of phosphorus release in the tests of worms without sludge maintained stable since the 6th day, and finally reached at about $0.10 \mathrm{mg}$ TP, a little higher than that in the tests of worms with activated sludge (Fig. 2). It is noted that the order of the amounts of TN released into the supernatant was as following: $1.4 \mathrm{mg} \mathrm{TN}$ in the tests of worms without sludge, $1.2 \mathrm{mg} \mathrm{TN}$ in the tests of worms with the sterilized sludge and $1.0 \mathrm{mg}$ TN in the tests of worms with the activated sludge.

Notably, whether worms was added in activated sludge or not, $\mathrm{PO}_{4}{ }^{3-}-\mathrm{P}$ and TP release into the supernatant of Group 2 tests with activated sludge was few, not as much as that of Group 1 tests with sterilized sludge. In the tests of activated sludge with worms, this phenomenon of few nutrients release confirmed results of recent researches [3-5,10-12,14,16-17,19], but such few nutrients release may not affect the performance of biological nutrients removal. It is well known that activated sludge mainly consists of bacteria. In the tests of activated sludge with worms, a dynamic balance was thus reached between activated sludge and worms, and the released phosphorus by worm's predation on activated sludge could be re-utilized by activated sludge which may be the cause of few nutrients release. In the tests of sterilized sludge without worms and worms without sludge, $\mathrm{TN}, \mathrm{PO}_{4}{ }^{3-}-\mathrm{P}$ and $\mathrm{TP}$ certainly released from decomposition of dead bacteria and dead worms and gradually accumulated in the supernatant due to the lack of re-utilization phosphorus by bacteria (Figs. 1 and 2).

\subsubsection{Statistical analysis}

For further investigating effect of main factors on nutrients release during worm's predation on sludge sewage, Pearson correlation analysis was carried out, and results are shown in Table 2.

For tests of worms with sterilized sludge, statistical analysis showed that time, worms (wet weight), sludge reduction rate (data of total suspended solids were not shown) were significantly correlated with $\mathrm{PO}_{4}{ }^{3-}-\mathrm{P}$ and TP concentrations in the supernatant, and
TN the concentration in supernatant was not correlated with other factors except worms (wet weight).

For tests of worms with activated sludge, statistical analysis showed that no factor was significantly correlated with phosphorus concentration in the supernatant, but two factors (time and worms (wet weight)) were significantly correlated with TN concentration in the supernatant.

\subsection{Test of radioisotope ${ }^{32} \mathrm{P}$ tracer}

\subsubsection{Distribution of phosphorus}

The radioactivity of ${ }^{32} \mathrm{P}$ and the total phosphorous (TP) amount in the activated sludge marked by ${ }^{32} \mathrm{P}$ were measured so as to determine the coefficient between unit Becquerel (Bq) and TP amount. As shown in Table 3, the conversion coefficient of $2.3174 \times 10^{-6} \mathrm{mgTP} / \mathrm{Bq}^{32} \mathrm{P}$ is used to calculate the phosphorus amount in activated sludge, supernatant and worms in the radioactivity ${ }^{32} \mathrm{P}$ tracer test.

Fig. 3 shows the ${ }^{32} \mathrm{P}$ distribution percentage among supernatant, sludge and worm during worm's predation on activated sludge. Results clearly showed that the ${ }^{32} \mathrm{P}$ tracer mainly distributed in the sludge and supernatant, and more release of ${ }^{32} \mathrm{P}$ into the supernatant occurred in the test of sludge with worms. After $24 \mathrm{~h},{ }^{32} \mathrm{P}$ concentration of supernatant in the test of sludge with worms was $9 \%$ higher than that in the test of the control (sludge without worms), and ${ }^{32} \mathrm{P}$ concentration of worm increased by $2.7 \%$.

The amount of ${ }^{32} \mathrm{P}$ release from activated sludge by worm's predation should be equal to the amount of ${ }^{32} \mathrm{P}$ increase in supernatant and worm. As shown in Figs. 3 and 4, after 24 h, not only the ${ }^{32} \mathrm{P}$ amount in the supernatant was 13.57 times of that in the worm (Fig. 3(b)), but also the amount of ${ }^{32} \mathrm{P}$ increase in the supernatant was much more than that in the worm (Fig. 4), e.g. $\triangle A(\mathrm{~S})$ from $0.58 \times 10^{-3} \mathrm{mgTP}$ at Hour 2 to $4.84 \times 10^{-3} \mathrm{mgTP}$ at Hour 24 compared with $\Delta A(\mathrm{~W})$ from $0.74 \times 10^{-3} \mathrm{mgTP}$ at Hour 2 to $1.87 \times 10^{-3} \mathrm{mgTP}$ at Hour 24 .

\subsubsection{Release of phosphorus}

The main disadvantage of sludge reduction induced by worms in recent researches is phosphorus release into effluent. In this study, the definition of phosphorus release into the supernatant is that the difference of ${ }^{32} \mathrm{P}$ concentration in the supernatant between

Table 3

Conversion coefficient between unit Becquerel (Bq) and total phosphorous (TP) amount in the radioisotope ${ }^{32} \mathrm{P}$ tracer test.

\begin{tabular}{|c|c|c|c|}
\hline TSS (mg) & $\mathrm{TP}$ (mg/gTSS) & Radioactivity $\left(\mathrm{Bq}^{32} \mathrm{P}\right)$ & Coefficient $\left(\mathrm{mgTP} / \mathrm{Bq}^{32} \mathrm{P}\right)$ \\
\hline 7.23 & 8.013 & $2.5 \times 10^{4}$ & $2.3174 \times 10^{-6}$ \\
\hline
\end{tabular}



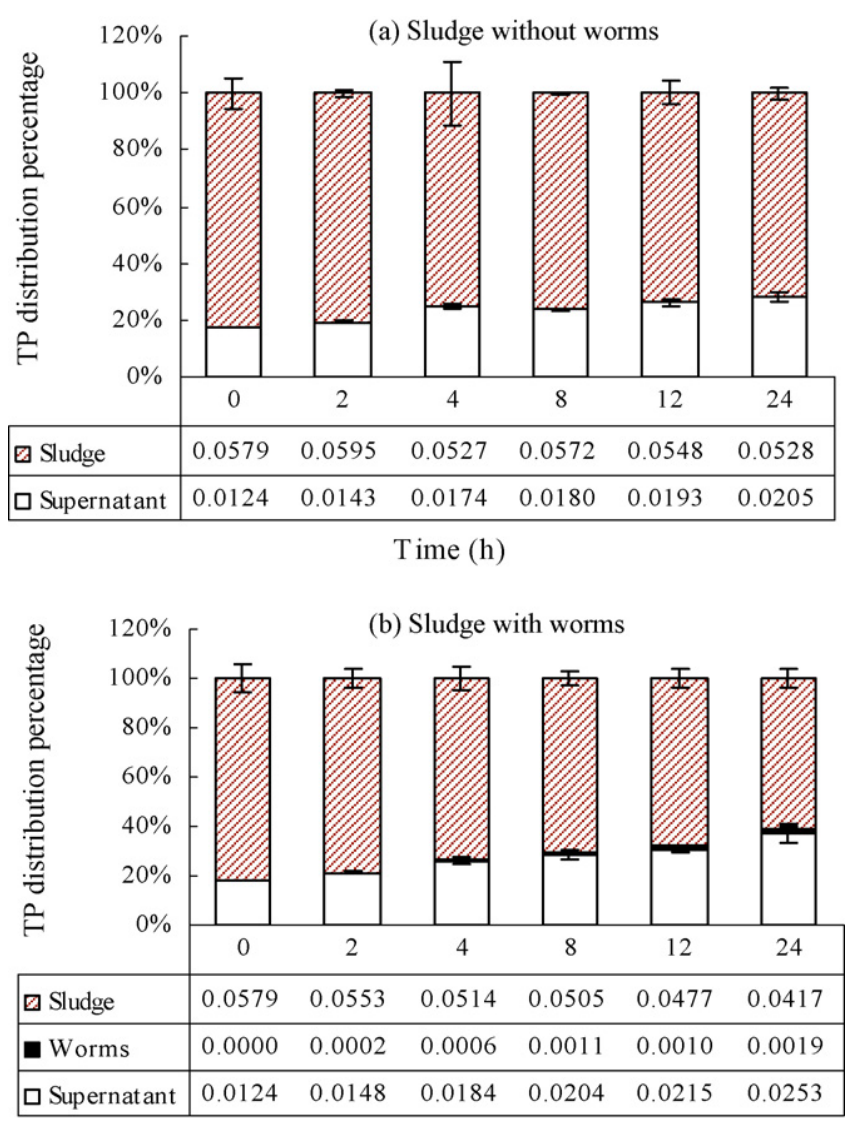

Time (h)

Fig. 3. Changes of ${ }^{32} \mathrm{P}$ distribution percentage among supernatant, sludge and worm in the radioisotope ${ }^{32} \mathrm{P}$ tracer test: (a) sludge without worms (the control), mgTP and (b) sludge with worms, mgTP.

the test of sludge with worms and the test of sludge without worms. As shown in Fig. 5, the release of ${ }^{32} \mathrm{P}$ into the supernatant within 24 h was only about $20 \%$, confirming the results of phosphorus release into effluent [10], though the predation of worm on activated sludge resulted in more release of ${ }^{32} \mathrm{P}$ into supernatant than the control. Therefore these results of the radioisotope ${ }^{32} \mathrm{P}$ tracer test clearly showed that less than $20 \%$ of phosphorus was released from worm's predation on activated sludge, which means the application of sludge reduction by oligochaetes

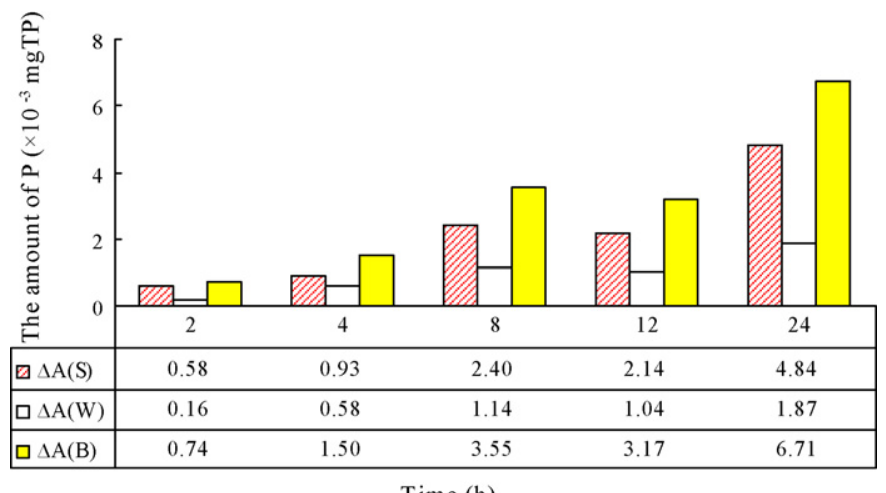

Fig. 4. The amounts of ${ }^{32} \mathrm{P}$ released from sludge to supernatant and worms in the radioisotope ${ }^{32} \mathrm{P}$ tracer test $\left(\triangle A(\mathrm{~S})\right.$-increase of TP in supernatant, $\times 10^{-3} \mathrm{mgTP}$; $\Delta A(\mathrm{~W})$-increase of TP in worm, $\times 10^{-3} \mathrm{mgTP} ; \Delta A(\mathrm{~B})$-release of TP from activated sludge, $\times 10^{-3} \mathrm{mgTP}$ ).

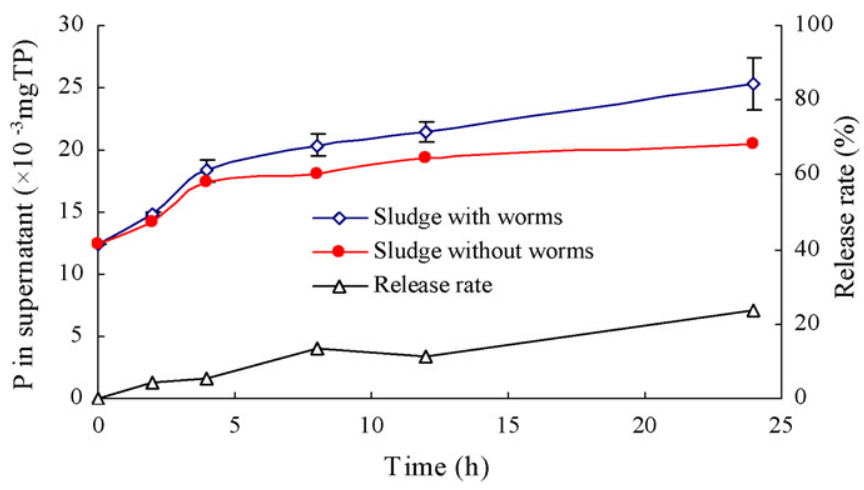

Fig. 5. Changes of ${ }^{32} \mathrm{P}$ concentration in supernatant of the radioisotope ${ }^{32} \mathrm{P}$ tracer test.

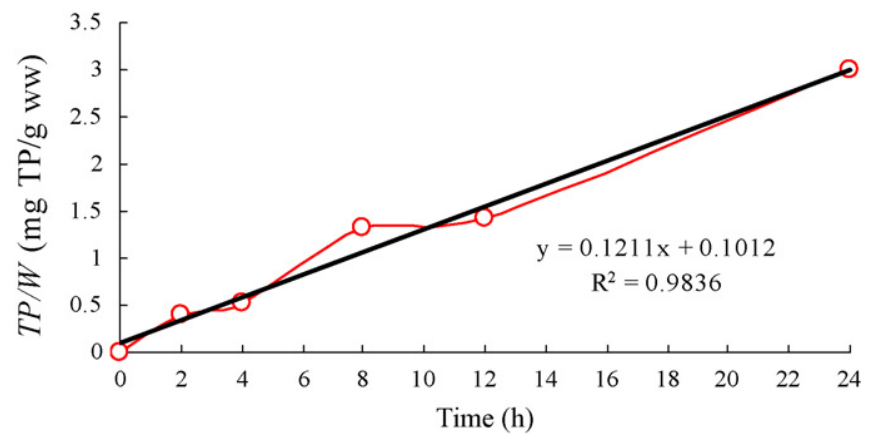

Fig. 6. Release rate of phosphorus into supernatant by worm's predation on activated sludge.

will not have serious impact on biological nutrients removal in practice.

Release of phosphorus into the supernatant is significantly correlated with worm's predation on activated sludge. As shown in Figs. 6 and 7, the release rate of phosphorus into supernatant caused by worm's predation on activated sludge was $0.1211 \mathrm{mgTP} / \mathrm{gWorm}$ (wet weight) $\mathrm{h}$ at $25^{\circ} \mathrm{C}$, and the coefficient of $(\Delta P)_{\mathrm{s}} /(\Delta P)_{\mathrm{w}}$ at $25^{\circ} \mathrm{C}$ was 2.47 , which means every increase of $1 \mathrm{mg}$ phosphorus in worms may result in $2.47 \mathrm{mg}$ phosphorus released into supernatant during worm's predation on activated sludge. However, to our knowledge, no comparisons with previous data can be made because this is the first study quantifying

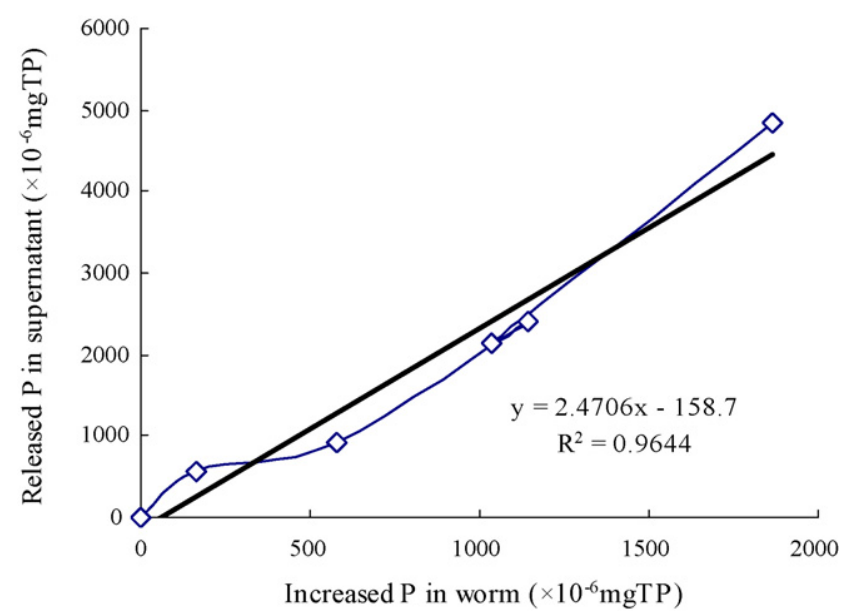

Fig. 7. The correlation between phosphorus increased in worm (wet weight) and phosphorus released in supernatant. 
phosphorus release rate for sludge reduction induced by worm's predation.

It is known that oligochaetes are widely present in natural waters, and play important role in nutrients cycling in lakes. Gardner et al. [23] reported the phosphorus release rate of benthic Tubificids in lake, i.e., inorganic $P$ release rate ranged from $0.16 \mathrm{nmolP}(\mathrm{mg} \text { ash-free dry weight })^{-1} \mathrm{~h}^{-1}$ at $5^{\circ} \mathrm{C}$ to $0.24 \mathrm{nmolP}(\mathrm{mg} \text { ash-free dry weight })^{-1} \mathrm{~h}^{-1}$ at $20^{\circ} \mathrm{C}$, organic $\mathrm{P}$ release rate ranged from $0.07 \mathrm{nmol} \mathrm{P}(\mathrm{mg}$ ash-free dry weight $)^{-1} \mathrm{~h}^{-1}$ at $5^{\circ} \mathrm{C}$ to $0.10 \mathrm{nmol} \mathrm{P}(\mathrm{mg} \text { ash-free dry weight })^{-1} \mathrm{~h}^{-1}$ at $20^{\circ} \mathrm{C}$. However, activated sludge is totally different from sediment because activated sludge containing live bacteria has higher percentage of organic matter. Thus the phosphorus release of worm's predation on activated sludge may be different from that of benthic oligochaetes, i.e., the phosphorus release of benthic oligochaetes mainly results from digestive and excretory processes [23]; the phosphorus release of worm's predation on activated sludge may be caused not only by digestive and excretory processes, but also by disintegration of activated sludge. Due to no measurement of phosphorus in excretion faeces during worm's predation on activated sludge in this study, further investigation will be needed for establishing which processes are main causes of phosphorus release in worm's predation on activated sludge. In addition, as an effective tool, the radioisotope ${ }^{32} \mathrm{P}$ tracer test can be used for determining the grazing rate of oligochaetes on activated sludge in order to accurately evaluate the performance of sludge reduction induced by oligochaetes.

\section{Conclusions}

Through investigation of nutrients release caused by worm's predation on sludge in batch tests and radioisotope ${ }^{32} \mathrm{P}$ tracer tests, conclusions are made as follows:

(1) Nutrients release into the supernatant occurred in the predation of worms on sludge, and phosphorus release was higher than nitrogen release. Addition of worms in sterilized sludge resulted in more nutrients release than that in activated sludge, and the nutrients ( $\mathrm{N}$ and $\mathrm{P}$ ) release was not serious in tests of worms with activated sludge.

(2) Statistical analysis results showed that time, worm (wet weight), sludge reduction rate were significantly correlated with phosphorus concentration in the supernatant, and worm (wet weight) was significantly correlated with TN concentration in the supernatant in the tests of worms with sterilized sludge. However, in the tests of worms with activated sludge, no factor significantly affected phosphorus concentration in the supernatant, but time and worm were two factors of significantly affecting TN concentration in the supernatant.

(3) Results of the radioisotope ${ }^{32} \mathrm{P}$ tracer test showed that ${ }^{32} \mathrm{P}$ mainly distributed in activated sludge and supernatant, and more release of ${ }^{32} \mathrm{P}$ into the supernatant occurred in the test of sludge with worms. After $24 \mathrm{~h},{ }^{32} \mathrm{P}$ concentration of supernatant in the test of sludge with worms was $9 \%$ higher than that in the test of sludge without worms, and ${ }^{32} \mathrm{P}$ concentration of worm increased by $2.7 \%$. And the release rate of phosphorus into supernatant caused by worm's predation on activated sludge was $0.1211 \mathrm{mgTP} / \mathrm{gWorm}$ (wet weight) h.

\section{Acknowledgements}

This research is financially supported by the National Natural Science Foundation of China (No. 50408021) and National Hi-Tech Development Program of China (No. 2007AA06Z347).

\section{References}

[1] Y.S. Wei, R.T. van Houten, A.R. Borger, D.H. Eikelboom, Y.B. Fan, Minimization of excess sludge production for biological wastewater treatment, Water Research 37 (2003) 4453-4467.

[2] C.H. Ratsak, S.A.L.M. Kooijman, B.W. Kooi, Modelling the growth of an oligochaete on activated sludge, Water Research 27 (1993) 739-747.

[3] C.H. Ratsak, Grazer induced sludge reduction in wastewater treatment. Ph.D. Thesis. Vrije University, the Netherlands, 1994.

[4] J.H. Rensink, R. Corstanje, J.H. van der Pal, A new approach to sludge reduction by metazoa, in: Proceedings of the 10th European Sewage and Reuse Symposium, IFAT 1996, Munchen, 1996, pp. 339-364.

[5] J.H. Rensink, W.H. Rulkens, Using metazoa to reduce sludge production, Water Science \& Technology 36 (11) (1997) 171-179.

[6] P.M.J. Janssen, W.H. Rulkens, J.H. Rensink, H.F. van der Poest, The potential for metazoa in biological wastewater treatment, Water Quality International (September/October 1998) 25-27.

[7] S.Y. Zhang, Polluted water treatment by the combining processes of membrane separation and biodegradation. Ph.D. Thesis. Research Centre for Eco-Environmental Sciences, Chinese Academy of Sciences, China, 2000.

[8] B.S. Lumxy, T. Kubo, K. Yamamoto, Sludge reduction potential of metozoa in membrane bioreactors, Water Science and Technology 44-10 (2001) 197202.

[9] C.H. Ratsak, Effects of Nais elinguis on the performance of an activated sludge plant, Hydrobiologia 463 (2001) 217-222.

[10] Y.S. Wei, R.T. van Houten, A.R. Borger, D.H. Eikelboom, Y.B. Fan, Comparison performances of membrane bioreactor (MBR) and conventional activated sludge (CAS) processes on sludge reduction induced by Oligochaete, Environmental Science \& Technology 37 (2003) 3171-3180.

[11] Y.S. Wei, J.X. Liu, The discharged excess sludge treated by Oligochaeta, Water Science and Technology 52-10 (11) (2005) 265-272

[12] Y.S. Wei, J.X. Liu, Effects of oligochaete reactor on treating the discharged excess sludge, Acta of Environmental Science 25 (2005) 803-808 (Chinese).

[13] R. Falconi, E. Cristiani, G. Tomba, F. Zaccanti, Sludge reduction induced by two species of Aeolosomatidae, in: Proceedings of the 10th International Symposium on Aquatic Oligochaeta, Wuhan, China 16-21 October 2006, 2006.

[14] Y.S. Wei, J.X. Liu, Sludge reduction with a novel combined worm-reactor, Hydrobiologia 564 (2006) 213-222.

[15] C.H. Ratsak, J. Verkuijlen, Sludge reduction by predation activity of aquatic oligochaetes in wastewater treatment plants: science or fiction? A review, Hydrobiologia 564 (2006) 197-211.

[16] P. Liang, X. Huang, Y. Qian, Excess sludge reduction in activated sludge process through predation of Aeolosoma hemprichi, Biochemical Engineering Journal 28 (2006) 117-122.

[17] P. Liang, X. Huang, Y. Qian, Y.S. Wei, G.J. Ding, Determination and comparison of sludge reduction rates caused by microfauna's predation, Bioresource Technology 97 (2006) 854-861.

[18] H.J.H. Elissen, T.L.G. Hendrickx, H. Temmink, C.J.N. Buisman, A new reactor concept for sludge reduction using aquatic worms, Water Research 40 (2006) 3713-3718

[19] X. Huang, P. Liang, Y. Qian, Excess sludge reduction induced by Tubifex tubifex in a recycled sludge reactor, Journal of Biotechnology 127 (2007) 443451.

[20] H.J.H. Elissen, E.T.H.M. Peeters, B.R. Buys, A. Klapwijk, W. Rulkens, Population dynamics of free-swimming Annelida in four Dutch wastewater treatment plants in relation to process characteristics, Hydrobiologia 605 (2008) 131142.

[21] N.P. Finogenova, T.M. Lobasheva, Growth of Tubifex tubifex (Oligochaeta, Tubificidae) under various trophic conditions, International Revue Der Gesamten Hydrobiologie 72-6 (1987) 709-726.

[22] APHA, Standard Methods for the Examination of Water and Wastewater, 20th edition, American Public Health Association/American Water Works Association/Water Environment Federation, Washington DC, USA, 2002.

[23] W.S. Gardner, T.F. Nalepa, M.A. Quigley, J.M. Malczyk, Release of phosphorus by certain benthic invertebrates, Canadian Journal of Fisheries and Aquatic Sciences 38 (1981) 978-981. 